\title{
Junctional Adhesion Molecules (JAMs) - New Players in Breast Cancer?
}

\author{
Gozie Offiah, Kieran Brennan and Ann M. Hopkins \\ Royal College of Surgeons in Ireland, Beaumont Hospital, Dublin \\ Ireland
}

\section{Introduction}

\subsection{Global incidence of breast cancer}

Worldwide, breast cancer remains a leading cause of death amongst women. Annually, it is estimated that breast cancer is diagnosed in over a million women (Kasler et al., 2009) with over 450,000 deaths worldwide (Tirona et al., 2010). The incidence of the disease is highest in economically-developed countries, with lower rates in developing countries. Despite continual advances in breast cancer care which have led to reduced mortality, however, the incidence of the disease is still rising. The decrease in breast cancer-specific mortality has been attributed to improvements in screening techniques which permit earlier detection, surgical and radiotherapy interventions, better understanding of disease pathogenesis and utilization of traditional chemotherapies in a more efficacious manner. Consequently, early stage breast cancer is now a curable disease while advanced breast cancer remains a significant clinical problem.

Breast cancer is a heterogeneous disease encompassing many subtypes, which differ both in terms of their molecular backgrounds and clinical prognosis. These breast cancer subtypes range from pre-invasive early stage disease to advanced invasive disease. The simplest classifications of disease subdivide breast cancer into pre-invasive and invasive forms; with the pre-invasive forms being ductal carcinoma in situ (DCIS) and lobular carcinoma in situ (LCIS). Carcinoma in situ is proliferation of cancer cells within the epithelial tissue without invasion of the surrounding stromal tissue (Bland \& Copeland, 1998). DCIS arises in the terminal ductal lobular units (TDLU) and in extra-lobular ducts while LCIS occurs in the breast lobules, and is recognisable histopathologically by the presence of populations of aberrant cells with small nuclei (Hanby \& Hughes, 2008). Invasive breast cancers are subclassified into invasive ductal breast cancer, invasive lobular breast cancer, inflammatory breast cancer and Paget's disease. Invasive ductal carcinoma (IDC) is the most common form of invasive breast cancer, accounting for around $85 \%$ of all cases.

DCIS is frequently considered as an obligate precursor to IDC, progressing from lower to higher grades and then onto invasive cancer with progressive accumulation of genomic changes (Farabegoli et al., 2002). However it has alternately been suggested that there exist genetically-distinct subgroups of DCIS, only some of which have the potential to progress to invasion (Shackney \& Silverman, 2003). Long-term natural history studies of DCIS have provided supportive evidence for both possibilities (Page et al., 1995; Collins et al., 2005; Sanders et al., 2005). Despite such controversies, the large extent to which the genome is 
altered in DCIS strongly suggests that genomic instability precedes phenotypic evidence of invasion (Hwang et al., 2004). This serves to underline the fact that malignant transformation in a heterogeneous disease like breast cancer is a dynamic process evolving through multiple multi-step pathway models.

Many factors are thought to be responsible for the development of breast cancer. Genetic factors play a vital role in the predisposition to breast cancer, with mutations of $B R C A 1$ and $B R C A 2$ genes accounting for $5-10 \%$ of breast cancer cases and being responsible for $80 \%$ of inherited breast cancers (Nathanson et al., 2001). On a more complex level, much insight has been gained from the genetic profiling of thousands of tumours to generate gene signatures of prognostic value (Sorlie et al., 2001; van 't Veer et al., 2002; van de Vijver et al., 2002), which have spurred the development of commercially-available diagnostic tests. The importance of reproductive factors in the aetiology of breast cancer is also well recognised with early onset of menarche, nulliparity, late menopause, endogenous and exogenous hormones representing the main risk factors (Reeves et al., 2000; Key et al., 2001; Howell \& Evans, 2011). Several other studies have reported an increased risk of breast cancer with lack of physical activity (especially in pre menopausal women), as well as increasing age and obesity (Clarke et al., 2006; Walker \& Martin, 2007; Harrison et al., 2009; Rod et al., 2009; Awatef et al., 2011). These risk factors accentuate the abnormal growth control of cells by increasing the circulating levels of oestrogen thereby promoting tumourigenesis within the breast microenvironment. A proper understanding of the breast cancer microenvironment is essential for understanding breast cancer, and will be explored in detail in the next sections.

\subsection{Breast structure and breast cancer microenvironment}

The breasts are modified sweat glands with a specialized function to produce milk. In the adult, the mature breast extends from the second ribs to the seventh rib and from the lateral border of the sternum to the midaxillary line and projects into the axilla at the axillary tail of Spence (Monkhouse, 2007). The breast is located within the superficial fascia of the anterior thoracic wall and is made up of 15-20 lobes of glandular tissue (Bland \& Copeland, 1998). Fibrous connective tissue forms the framework that supports the lobes and adipose tissue which fills the space between the lobes. Each lobe of the mammary gland terminates in a lactiferous duct which opens onto the nipple and is lined with breast epithelial tissue. These ducts have a sinus at the base beneath the areola called the lactiferous sinus (Figure 1).

Breast cancers are characterised by abnormal proliferation of breast epithelial cells and mostly originate in milk ducts (Sainsbury et al., 2000). Normal milk ducts consist of an outer myoepithelial cell layer and an inner luminal epithelial layer. Myoepithelial cells, which are of ectodermal origin, lie between the surface epithelial cells and the basal lamina. Both the epithelial and myoepithelial cells of the breast duct lie on a basement membrane composed of extracellular matrix factors secreted by those cells (Figure 2). The basement membrane is important for defining the barriers of the normal duct, and thus alterations in the basement membrane have been implicated in abnormal cell differentiation and the formation of metastases (Kleinman et al., 2001).

Proliferation of cells within the breast ducts is controlled by growth-promoting protooncogenes and growth-inhibiting tumour suppressor genes. In most cases, normal cells divide as many times as needed and then stop. Carcinogenic mutations in either (or both) 
oncogenes and tumour suppressor genes (along with subsequent interactions between defective genes and the breast microenvironment) alter not just cell proliferation, but also differentiation, survival and genome stability (Hahn \& Weinberg, 2002) of breast cells, leading to abnormal cell growth and potentially cancer.

Much evidence supports the contention that the pathogenesis of breast cancer is influenced by complex interactions between ductal epithelial cells and the cells that compose the tumour microenvironment (Weaver et al., 1996; Polyak \& Hu, 2005; Hu et al., 2008). The next section will focus on the cells of the microenvironment with respect to normal breast tissue structure and also their possible involvement in breast tumourigenesis.

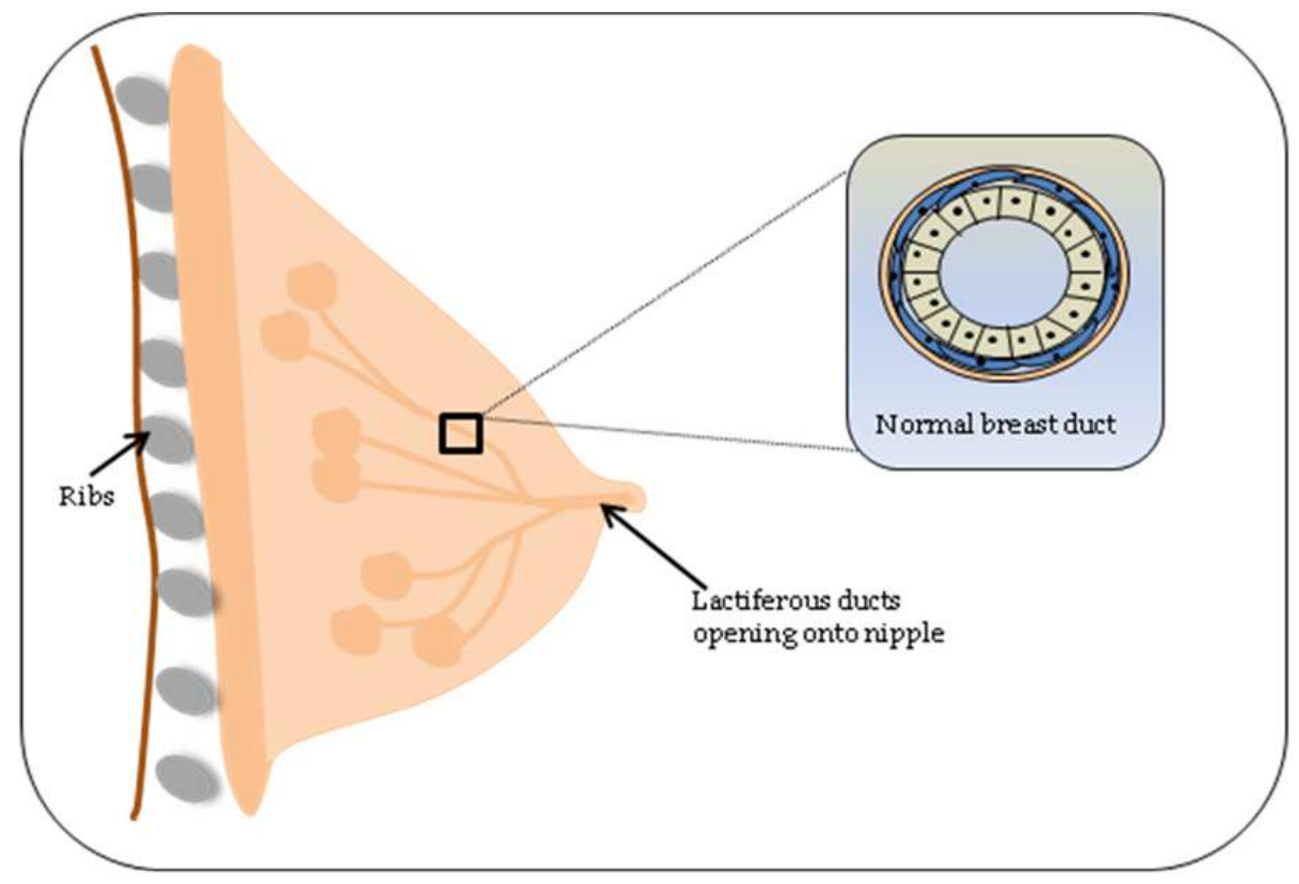

Fig. 1. Structure of the breast showing lobules and lactiferous ducts terminating at the nipple 


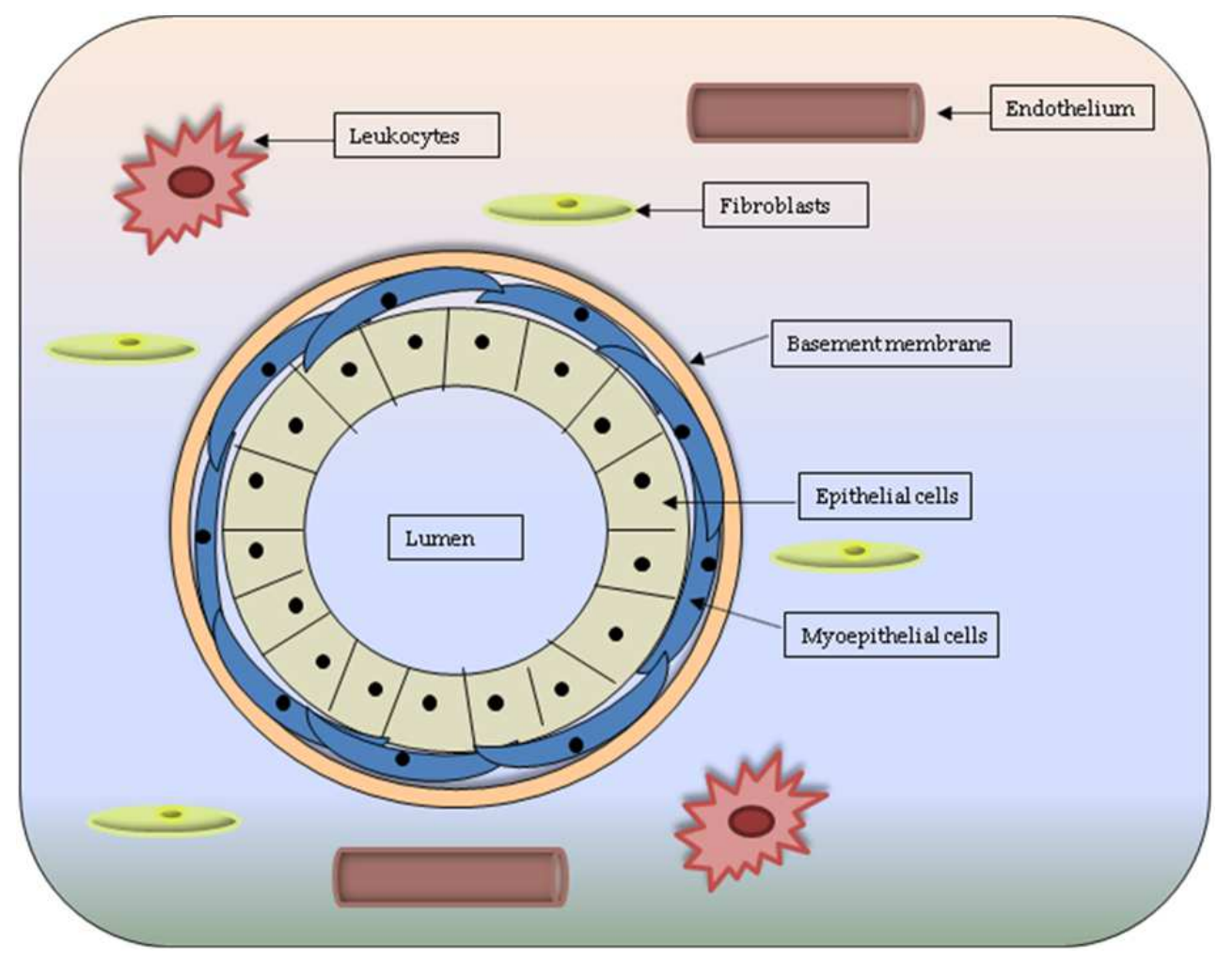

Fig. 2. Diagram of a normal breast duct depicting cells of the microenvironment.

\subsubsection{Cells of the breast microenvironment}

The abnormal epithelial cells composing a breast carcinoma form only one component of a complex microenvironment which influences the success or failure of a developing tumour. In fact the breast tumour microenvironment consists also of multiple cell types; including myoepithelial cells, fibroblasts, endothelial cells and immune cells such as macrophages (Figure 2). In terms of their likely contributions to breast tumourigenesis, fibroblasts and macrophages are often considered as tumour promoters through downstream signalling from various secreted factors, while the endothelial cells which develop in tumourassociated blood vessels also support cancer development. In contrast, myoepithelial cells exert functions broadly considered as tumour-suppressive.

Fibroblasts are an important structural component of the extracellular environment in the normal breast, where they help control the development of the breast epithelium (McCave et al. 2010). Their secretion of extracellular matrix components and cytokines has also implicated them in tumorigenic growth associated with invasive breast cancer (Orimo et al., 2005), and differences in cellular responsiveness to normal versus tumour-derived fibroblasts have been noted (Sadlonova et al., 2005). Many studies have highlighted the 
potential involvement of fibroblasts in promoting tumour progression both at genomic and transcriptomic levels, with reports of altered genetic signatures between normal and tumour-associated fibroblasts supporting a complex role for fibroblasts in influencing tumour progression (Hu et al., 2005; Hu et al., 2008; Ma et al., 2009).

Macrophages within the breast cancer microenvironment have been shown to enhance tumour growth through the secretion of pro-angiogenic factors like vascular endothelial growth factor (VEGF); (Murdoch et al., 2004; Lamagna et al., 2005 ; Lewis \& Hughes, 2007). They have also been implicated in promoting a metastatic phenotype, via the secretion of pro-migratory factors such as EGF (Wyckoff et al., 2004) which enhance cellular dissemination from a primary tumour. Accordingly, the enhanced physical juxtaposition of macrophages, tumour cells and endothelial cells has been proposed as a new prognostic histopathological marker associated with increased risk of metastases in human breast cancer (Robinson et al., 2009).

Endothelial cells which line the blood vessels are derived from angioblasts forming the vascular network. Enhanced vessel density occurring as a result of tumour-associated angiogenesis is a major contributor to both the survival of primary breast tumours (via the delivery of systemic growth factors) and the risk of metastasis (via increased access of disseminated tumour cells to a circulatory source). Expression of pro-angiogenic factors such as VEGF has been shown to increase in haematological malignancies (Fiedler et al., 1997; Molica et al., 1999) in addition to solid tumours including breast, renal, ovarian, gastric and lung cancer (Patel et al., 2009; Burger, 2011; Gou et al., 2011; Sharma et al., 2011). VEGF promotes neovascularisation via mitogenic and pro-migratory effects on endothelial cells (Asahara et al., 1999).

Finally, myoepithelial cells are known to play a role in the formation of the basement membrane and thereby assist in maintaining polarity of the breast ductal epithelium. They also interact with epithelial cells to regulate the cell cycle and suppress breast cancer cell growth, invasion and angiogenesis (Weaver et al., 1996; Alpaugh et al., 2000; Barsky, 2003). Tumour and non-tumour primary myoepithelial cells have been described to differ in functional properties relating to the secretion of extracellular matrix components such as laminin-1 (Gudjonsson et al., 2002), and accordingly myoepithelial cells reportedly lose their established tumour-suppressive properties during tumour progression (Polyak \& Hu, 2005). Taken together, the many cell types within the breast tumour microenvironment can both individually and coordinately regulate several functions relevant to tumour progression. In order to better understand their relative contributions to breast cancer, it is necessary to dissect the signals that regulate their own functions. Since adhesive functions are central to the behaviour of all of these cell types, the remainder of this chapter will focus on their potential regulation by a family of adhesion proteins termed the Junction Adhesion Molecules (JAMs), whose role in breast cancer initiation and progression is just emerging.

\section{Cell-cell adhesion and the functional roles of JAMs in epithelial/endothelial cells}

\subsection{Introduction to cell-cell adhesion complexes and JAMs}

Cells within the breast tumour microenvironment physically interact with each other and with the extracellular matrix through a range of cell adhesion proteins. Cell adhesion proteins play fundamental roles in normal physiology (such as the control of cell polarity and epithelial barrier function), but their dysregulation has been shown to participate in 
tumour cell migration, invasion and adhesion (for review, see Brennan et al.,2010). Adhesion proteins rarely exist in isolation from each other on the cell membrane, rather they form components of multi-cellular adhesion complexes containing a network of adhesion, scaffolding and signalling proteins. Breast epithelial cells express various types of adhesion complexes, namely hemidesmosomes and focal adhesions at the cell-matrix interface, with tight junctions, adherens junctions, desmosomes and gap junctions at the cell-cell interface. Collectively, adhesion complexes are composed of integral membrane proteins and cytoplasmic scaffolding proteins that organise signalling complexes and anchor cell-cell contacts to intermediate filaments (at desmosomes and hemidesmosomes) or to actin filaments (at adherens junctions, tight junctions and focal adhesions).

Tight junctions (TJs) play a vital role in regulating the paracellular flux of ions, small molecules and inflammatory cells as well as defining distinctly-polarized membrane domains and facilitating bi-directional signalling between the intracellular and extracellular compartments. These functions of the TJ are regulated by the balance of three different types of integral membrane proteins; (1) Occludins and Tricellulin, (2) Claudins and (3) Immunoglobulin Superfamily (IgSF) members. Of most interest in this chapter is the Junctional Adhesion Molecule (JAM) subfamily of the IgSF, and its potential contribution to cancer initiation and progression.

The JAM family consists of 5 proteins (JAM-A, -B, -C, -4, -L) which are major components of TJs in endothelial and epithelial cells in a variety of vertebrate and invertebrate tissues (Martin-Padura et al., 1998; Liang et al., 2000; Liu et al., 2000; Arrate et al., 2001; AurrandLions et al., 2001; Itoh et al., 2001; Hirabayashi et al., 2003; Tajima et al., 2003). JAM proteins are also expressed on the surface of haematopoetic cells such as platelets, neutrophils, monocytes, lymphocytes, leukocytes and erythrocytes; in addition to connective tissue cells such as fibroblasts and smooth muscle cells (Azari et al., 2010; Kornecki et al., 1990; Naik et al., 1995; Malergue et al., 1998; Williams et al., 1999; Cunningham et al., 2000; Palmeri et al., 2000; Arrate et al., 2001; Aurrand-Lions et al., 2001; Moog-Lutz et al., 2003; Morris et al., 2006). JAMs are type I transmembrane proteins consisting of an N-terminal signal peptide, an extracellular domain (consisting of two immunoglobulin-like domains), a single membranespanning domain and a short cytoplasmic tail (Martin-Padura et al., 1998; Liu et al., 2000; Sobocka et al., 2000; Aurrand-Lions et al., 2001; Naik et al., 2001; Santoso et al., 2002). The cytoplasmic tail is thought to play a major role in the assembly of adhesion signalling complexes, since it has been reported to bind to PDZ domain-containing scaffold proteins such as ZO-1 (Bazzoni et al., 2000; Ebnet et al., 2000), AF-6 (Ebnet et al., 2000) and MUPP1 (Hamazaki et al., 2002).

JAMs -A, -B and -C exhibit a short cytoplasmic tail of 45-50 residues that ends with a type II PDZ binding motif, while JAM-4 and JAM-L have longer cytoplasmic tails (of 105 and 98 residues respectively). JAM-4 and JAM-L differ in that the cytoplasmic tail of the former ends in a canonical type I PDZ binding motif, while that of the latter lacks a PDZ-binding motif (Mandell \& Parkos, 2005). The cytoplasmic tails of JAM proteins also contain consensus phosphorylation sites that may serve as substrates for protein kinase $\mathrm{C}$, protein kinase A and Casein Kinase II (Naik et al., 1995; Cunningham et al., 2000; Ozaki et al., 2000; Sobocka et al., 2000; Arrate et al., 2001; Naik et al., 2001). Indeed, evidence suggests that specific phosphorylation sites may be critical for targeting of JAMs to intercellular junctions (Ozaki et al., 2000; Ebnet et al., 2003). 
JAM proteins have been implicated in a diverse array of physiological functions involving cell-cell adhesion/barrier function (Liang et al., 2000; Liu et al., 2000; Mandell et al., 2004), leukocyte migration (Martin-Padura et al., 1998; Palmeri et al., 2000; Johnson-Leger et al., 2002; Ostermann et al., 2002), platelet activation (Kornecki et al., 1990; Naik et al., 1995; Gupta et al., 2000; Ozaki et al., 2000; Sobocka et al., 2000; Naik et al., 2001; Babinska et al., 2002; Babinska et al., 2002) and angiogenesis (Naik et al., 2003; Naik et al., 2003). These functions will be further discussed in the next sections.

\subsection{JAM proteins regulate epithelial/endothelial cell-cell adhesion and barrier function} JAM proteins are well-known to be important for cell-cell adhesion in both epithelial and endothelial cells (for review see Mandell \& Parkos, 2005), but emerging evidence supports the possibility that they also regulate cell-matrix adhesion complexes. Interestingly, JAM-A knockdown in endothelial cells and MCF7 breast cancer cells has been shown to reduce adhesion to fibronectin and vitronectin (McSherry et al., 2011; Naik \& Naik, 2006), while JAM-C overexpression in endothelial cells reportedly decreases attachment to fibronectin, vitronectin, and laminin ( $\mathrm{Li}$ et al., 2009). This apparent incongruity may relate to the fact that JAM-A may activate $\beta 1$ integrins (McSherry et al., 2011), while JAM-C has conversely been described to inactivate $\beta 1$ integrins (Li et al., 2009). An inverse relationship between JAMs $A$ and $-C$ has also been observed in terms of tight junction function, with JAM-A promoting tight junction sealing while phosphorylated JAM-C increases paracellular leakiness due to its redistribution away from TJs (Li et al., 2009). Furthermore, adhesion of the lung carcinoma cell line NCI-H522 to endothelial cells was significantly blocked by soluble JAMC (Santoso et al., 2005).

The contribution of JAM proteins to cell-cell adhesion and the assembly of epithelial/endothelial TJs relates to their ability to promote the localization of ZO-1, AF-6, CASK and occludin at points of cell-cell contact. Evidence suggests that both homophilic and heterophilic interactions, as well as an intact PDZ binding motif, are important for such protein functions of JAMs. Accordingly, JAMs have been shown to physically interact with the PDZ proteins, ZO-1 (Bazzoni et al., 2000; Ebnet et al., 2000), AF-6 (Ebnet et al., 2000), CASK (Martinez-Estrada et al., 2001), PAR-3 (Ebnet et al., 2001; Itoh et al., 2001) and MUPP-1 (Hamazaki et al., 2002); which are involved in actin cytoskeletal rearrangement (Fanning et al., 2002), cell signalling (McSherry et al., 2011; Boettner et al., 2000) and the control of cell polarity. However JAMs can also bind to non-PDZ proteins such as cingulin (Bazzoni et al., 2000), and indirectly bind occludin (Bazzoni et al., 2000) and claudin 1 via their interactions with ZO-1 (Hamazaki et al., 2002). Although the manner in which JAMs interact with some of these proteins is incompletely understood, it appears that homo-dimerisation of JAM proteins is important for regulating some key downstream functions. This has been illustrated by the fact that dimerisation-blocking anti-JAM-A antibodies (Liu et al., 2000) and soluble Fc-JAM-A (Liang et al., 2000) delay the recovery of electrical resistance (a marker of TJ function) in epithelial cells following transient depletion of extracellular calcium.

\subsection{JAM proteins regulate epithelial/endothelial migration}

In general cell adhesion and cell migration are inversely related, and serve to control important physiological functions and pathophysiological events. However, in the case of JAM family members, close functional associations with cell polarity proteins may act as a switch between increased adhesion (predisposing to slow, directional migration) and decreased 
adhesion (predisposing to faster, more random motility). For example, JAM-A re-expression in JAM-A-/- mouse endothelial cells has been shown to reduce the occurrence of spontaneous and random motility. This ability of JAM-A to influence the polarised movement of cells was reliant on its interaction with polarity proteins through its PDZ binding motif (Bazzoni \& Dejana, 2004). JAM-A deletion mutants lacking their PDZ-binding residues have been shown to have increased availability of Par3 (Ebnet et al., 2001), resulting in PKC $\zeta$ inactivation and the loss of contact-dependent inhibition of cell motility (Mishima et al., 2002; Bazzoni \& Dejana, 2004). These data show that loss of functional JAM-A results in faster random motility with reduced cell-cell contact inhibition of migration. Interestingly, JAM-C redistribution away from TJs stimulates $\beta 1$ and $\beta 3$ integrin activation, resulting in increased cell migration and adhesion (Aurrand-Lions et al., 2001). Furthermore, JAM-A and JAM-4 have been found to induce the formation of actin-based membrane protrusions, an essential part of cell migration, in endothelial and COS-7 cells (Mori et al., 2004). Together these data suggest loss of JAM-A promotes random motility, while JAM-A, JAM-C and JAM-4 promote directional cell migration through their effects on integrin function and cytoskeletal reorganization.

In the context of cancer, knockdown of JAM-A has been shown to enhance invasiveness of the breast cancer cell lines MDA-MB-231 and T47D, and the renal cancer cell line RCC4 (Naik et al., 2008; Gutwein et al., 2009). Conversely, the overexpression of JAM-A in MDAMB-231 cells reportedly inhibits both migration and invasion through collagen gels (Naik et al., 2008), suggesting that loss of JAM-A expression increases cancer cell dissemination and invasion. However, the specific contribution of JAM-A to breast cancer progression remains controversial. McSherry et al showed a significant association between high JAM-A gene or protein expression and poor survival in 2 large cohorts of patients with invasive breast cancer, and concurrently a decrease in the migratory abilities of high JAM-A-expressing MCF-7 cells upon knockdown or functional inhibition of JAM-A (McSherry et al., 2009). Reduced motility after JAM-A loss was subsequently linked to reduced interactions between JAM-A, AF-6 and the Rap1 activator PDZ-GEF2, resulting in reduced activity of Rap1 GTPase (McSherry et al., 2011), a known activator of $\beta 1$-integrins (Sebzda et al., 2002) and a regulator of breast tumourigenesis (Itoh et al., 2007). Complementary evidence in a recent publication by Gotte et al. has also supported the theory that JAM-A overexpression is of more functional relevance in breast cancer than JAM-A loss, since over-expression of micro RNA (miR)-145 in breast cancer cells led to a decrease in cellular migration and invasion via downregulation of JAM-A expression (Gotte et al., 2010). Still more recently (during the proofing stage of this chapter), additional histopathological evidence has been provided for a link between JAM-A over-expression and poor prognosis in breast cancer patients (Murakami et al., 2011). This, along with the finding that JAM-A promotes the survival of mammary cancer cells (Murakami et al., 2011), strongly suggests that JAM-A depletion or antagonism could offer promise in reducing breast tumour progression. Furthermore, depletion of JAM-A has been found to inhibit bFGF-induced migration of human umbilical vein endothelial cells (HUVEC) on vitronectin, through effects on integrin function (Naik \& Naik, 2006). In other cell systems, silencing of the JAM-A gene has been shown to block the migration of inflamed smooth muscle cells (Azari et al., 2010) and to increase the random motility of dendritic cells (Cera et al., 2004). JAM-A has also been shown to be required for neutrophil directional motility (Corada et al., 2005), and to promote neutrophil chemotaxis by controlling integrin internalization and recycling (Cera et al., 2009). Thus while the area remains controversial, increasing evidence is suggesting that JAMs promote migration and 
invasion through the regulation of integrin expression and activation (McSherry et al., 2011; Naik \& Naik, 2006; Li et al., 2009; McSherry et al., 2009).

In breast cancer, the formation of metastases at distant sites is the leading cause of cancerrelated death. In order for breast cancer cells to metastasize, they must first migrate out of the primary tumour before ever reaching a distant organ and potentially proliferating into a secondary tumour. While JAMs are already known to regulate migration, the possibility that they are also involved in the regulation of proliferation will be referred to in section 3.3 of this chapter.

All together these data highlight the role of JAM family members in controlling the balance between cell adhesion and migration. Although much remains to be understood about the exact role of JAMs in breast cancer cell migration, the classic description of tumours as "wounds which do not heal" (Riss et al., 2006) suggests that the migratory mechanisms employed by JAMs in physiological responses (such as wound healing) may also be utilised by cancer cells to promote tumour progression or survival.

\subsection{Potential role of JAM proteins in epithelial/endothelial differentiation}

In previous sections we discussed the biphasic role of JAM family members in regulating cell adhesion and migration. In this section we will outline the emerging contribution of the JAM family to cellular differentiation. Cell differentiation in the context of normal tissue usually involves the transition from an undifferentiated stem/progenitor cell to a terminally-differentiated cell such as an epithelial, muscle or nerve cell.

JAM-A, JAM-B, JAM-C and JAM-4 have been found to be highly expressed on hematopoietic stem cells (HSCs) in the bone marrow, with their expression decreasing during the acquisition of a more differentiated state (Nagamatsu et al., 2006; Sakaguchi et al., 2006; Sugano et al., 2008; Praetor et al., 2009). Furthermore JAM-A expression has been reported to be high on undifferentiated HC11 mammary epithelial cells relative to differentiated cells (Perotti et al., 2009). In support of a potential association between high JAM-A and poor differentiation status, high JAM-A gene or protein expression has been associated with a poorer grade of differentiation in tissues from patients with invasive breast cancer (McSherry et al., 2009). Conversely, JAM-A has been found to mediate the differentiation of CD34+ progenitor cells to endothelial progenitor cells and to facilitate CD34+ cell-induced re-endothelialization in vitro (Stellos et al., 2010). This suggests that JAM-A is required for circulating CD34+ progenitor cells to recognise a site of injury, differentiate into endothelial cells and proliferate to repair the injured endothelium. In addition, JAM-A is reportedly upregulated during the differentiation of pancreatic AR42J cells (Yoshikumi et al., 2008), while JAM-A mRNA and protein levels have been shown to be increased during differentiation of human monocytic cell THP-1 into mature dendritic cells (Ogasawara et al., 2009). JAM-L is also induced during differentiation of myeloid leukaemia cells, with expression of JAM-L in myeloid leukaemia cells resulting in enhanced cell adhesion to endothelial cells (Moog-Lutz et al., 2003). This upregulation of JAM-A during differentiation is reportedly followed by increased expression of the polarity proteins par3 and PKC入 (Yoshikumi et al., 2008), which have been previously shown to affect cell polarity and migration. While these data suggest conflicting roles for JAMs in stem cell populations versus their role in differentiation, at this early stage the exact role(s) of JAMs in stem cell renewal or differentiation can only be speculated upon. Fundamentally, it is also unknown whether the expression of JAMs is actively required or 
passively upregulated in stem cell populations. However, based on the increased expression of JAM-A in poorly-differentiated breast cancers (McSherry et al., 2009) and the emerging role of JAM-A in regulating proliferation and apoptosis (Azari et al., 2010; Nava et al., 2011; Naik et al., 2003; Murakami et al., 2011), it will be interesting to determine if JAM-A is upregulated on cancer stem cell populations and whether its expression promotes self-renewal.

\section{Functional regulation of cells in the breast cancer microenvironment by JAMs}

\subsection{JAM proteins regulate endothelial angiogenesis}

As already alluded to, JAM proteins are highly expressed on endothelial cells and have been crucially implicated in the control of barrier function and cell motility. In the context of cancer, however, endothelial cells assume a new importance via the development of neovascularisation sites to support growing tumours (Hanahan \& Folkman, 1996). This section will review the evidence currently linking JAM proteins to angiogenesis as a contributory mechanism to cancer progression.

Angiogenesis in response to enhanced growth factor signalling is of particular relevance in tumour microenvironments. A body of work from Naik et al has convincingly shown an important role for JAM-A in angiogenesis induced by basic fibroblast growth factor (bFGF). Specifically, bFGF signalling facilitates the disassembly of an inhibitory complex between JAM-A and av 33 integrin, permitting JAM-A-dependent activation of MAP kinase which leads to endothelial tube formation, a surrogate for angiogenesis (Naik et al., 2003). JAM-A has also been shown to activate extracellular signal-related kinase (ERK) signalling in response to bFGF, facilitating endothelial migration (Naik et al., 2003) in a matrix-specific context (Naik \& Naik, 2006). In vivo, JAM-A expression has been linked with the very early stages of murine embryonic vasculature development (Parris et al., 2005), and although deletion of JAM-A appears to be dispensable for vascular tree development, homozygous JAM-null mice were found to be incapable of supporting FGF-2-induced angiogenesis in isolated aortic ring assays (Cooke et al., 2006). In the context of tumour neovascularisation, others have reported reduced angiogenesis in a model of pancreatic carcinoma in JAM-Anull mice (Murakami et al., 2010).

Other JAM family members appear to contribute similarly to angiogenesis; with functional blockade of JAM-C being shown to decrease aortic ring angiogenesis and block angiogenesis in hypoxic vessels of the murine retina (Lamagna et al., 2005; Orlova et al., 2006). Furthermore, soluble JAM-C shed into the serum of patients with inflammatory conditions (presumably following cleavage by ADAM enzymes) was noted to induce endothelial tube formation in a Matrigel model (Rabquer et al., 2010). An interesting dichotomy, however, is that amplification of JAM-B in a trisomy-21 mouse model of Down's syndrome has been linked with reductions in VEGF-induced angiogenesis and thus anti-tumour effects in a lung carcinoma model in these mice (Reynolds et al., 2010).

Taken together, these studies illustrate that by influencing angiogenic functions in endothelial cells, JAMs may indirectly influence the ability of tumours to survive and progress. While there appears to be a consensus that JAMs $-\mathrm{A}$ and $-\mathrm{C}$ activate signalling cascades that promote angiogenesis, it is possible that clear roles for the other family members in the regulation of angiogenesis will also emerge in time. It is tempting to speculate that pharmacological antagonism of JAMs will show promise as an option for 
blocking tumour progression, similar to the VEGF-A-neutralizing antibody bevacizumab (avastin) (Van Meter \& Kim, 2010).

\subsection{JAM proteins regulate trafficking of leukocytes}

In addition to the potential regulatory roles of JAM proteins on the vascular endothelium, effects exerted on JAM-expressing leukocytes within the breast tumour microenvironment may also have relevance to cancer progression. For instance, JAMs are known to play important roles in the transendothelial migration of monocytes, which differentiate into macrophages once in the breast tissue. Accordingly, a function-blocking monoclonal antibody directed against JAM-A (BV11) has been described to inhibit spontaneous and chemokine-induced monocyte transmigration both in vitro and in vivo (Martin-Padura et al., 1998). Furthermore, treatment of mice with a monoclonal antibody directed against JAM-C has been shown to reduce macrophage infiltration into a murine lung tumour model (Lamagna et al., 2005), and to promote reverse transmigration of monocytes back into the bloodstream from inflamed tissue sites (Bradfield et al., 2007). Given the existence of a breast tumour-promoting paracrine loop between epidermal growth factor secreted by macrophages and colony-stimulating factor-1 secreted by tumour cells (Goswami et al., 2005), this implies that JAM-based regulation of monocyte transmigration could have a profound and self-amplifying influence on macrophage trafficking and tumour proliferation.

In the context of leukocytes other than monocytes/macrophages, many studies have implicated JAMs in the functional control of neutrophil transmigration across both epithelial (Zen et al., 2004; Zen et al., 2005) and endothelial (Sircar et al., 2007; Woodfin et al., 2007) barriers. As yet nothing is known about JAM-dependent events that might control neutrophil trafficking or activation within the breast tissue, despite the fact that neutrophils accumulate in highly aggressive inflammatory breast cancers. In other tissues, JAM-A has been shown to be required for efficient infiltration of neutrophils into the inflamed peritoneum or into the heart upon ischemia-reperfusion injury; as evidenced by increased adhesion and impaired transmigration in JAM-A-deficient mice (Corada et al., 2005). Interestingly, in this model JAM-A expression on the neutrophil appears to be more important than that on the endothelium; since selective loss of endothelial JAM-A did not phenocopy the transmigration deficits (Corada et al., 2005). In addition, soluble JAM-A shed from cultured endothelial cells has been shown to reduce in vitro transendothelial migration of neutrophils and to decrease neutrophil infiltration in vivo (Koenen et al., 2009).

Recent evidence also proves that family members other than JAM-A can participate in leukocyte trafficking, with JAM-C over-expressing mice exhibiting an increased accumulation of leukocytes into inflammatory sites or during ischaemia/reperfusion injury, while JAM-C neutralization or loss reduces leukocyte recruitment in models of lung, kidney or muscular inflammation (Aurrand-Lions et al., 2005; Scheiermann et al., 2009). Finally leukocytic expression of JAM-L has been shown to promote attachment to endothelium (Luissint et al., 2008), and functional inhibition of JAM-B is reported to decrease migration of peripheral blood lymphocytes across cultured human umbilical vein endothelial cells (HUVECs) (Johnson-Leger et al., 2002).

Collectively these data highlight an important role for JAMs in the migration of immune cells across endothelia, a mechanism that could be hijacked by JAM-overexpressing cancer cells as they leave the breast and invade into blood vessels. 


\subsection{JAM proteins and the regulation of stromal cells}

The final grouping of breast cancer microenvironmental cells which will be discussed are stromal cells, broadly including fibroblasts and myoepithelial cells. Although little is known about JAM-mediated control of breast stromal cells specifically, insights from other cellular systems may suggest that this multifunctional family of proteins could have a hand in influencing the mesenchymal element of tumourigenic processes.

JAM-C expression has been noted on the surface of primary fibroblasts derived from human lung, skin and cornea (Morris et al., 2006). The same authors observed JAM-A and JAM-C expression on the widely-studied NIH-3T3 fibroblast cell line. Interestingly, high JAM-C expression on synovial fibroblasts has been associated with the pathology of murine experimental arthritis, and JAM-C antagonism shown to have functional benefits in reducing the severity of inflammation (Palmer et al., 2007). An immunohistochemical study in human arthritis has also demonstrated JAM-C expression on the synovial fibroblasts of both osteoarthritis and rheumatoid arthritis patients, in conjunction with JAM-C-dependent adhesion of myeloid cells to these fibroblasts (Rabquer et al., 2008). Enhanced expression of JAM-A has also been described on the skin of patients with the inflammatory disorder systemic sclerosis, in comparison to that on normal dermal fibroblasts (Hou et al., 2009).

Aside from facilitating adhesion of leukocytic cells to stromal elements such as fibroblasts, another way in which JAM family members could influence the breast cancer microenvironment is by altering proliferation of fibroblasts or other accessory cells. JAM-A has been reported to be required for proliferation of vascular smooth muscle cells, since JAM-A gene silencing exerted anti-proliferative effects in this system (Azari et al., 2010). Whether this is through direct or indirect mechanisms remains uncertain, particularly in light of conflicting evidence in intestinal epithelial cells suggesting that JAM-A expression restricts proliferation by inhibiting Akt-dependent Wnt signalling (Nava et al., 2011). However functional inhibition of the extracellular domain of JAM-A has been shown to inhibit bFGF-induced endothelial cell proliferation, and overexpression of JAM-A was also found to increase endothelial cell proliferation (Naik et al., 2003). Accordingly, very recent evidence has suggested that JAM-A expression exerts a negative tone on apoptosis in the mammary epithelium (Murakami et al., 2011). It is likely that processes as crucial as proliferation are strictly regulated in a spatial manner, which could account for tissuespecific differences as observed from the little available evidence to date. Whether or not JAM family members may influence proliferation of breast stromal cells like fibroblasts and the myoepithelium remains to be investigated. However, it is tempting to speculate that the acquisition of a proliferative phenotype in tumours may be co-ordinately linked to the promigratory "mesenchymal" phenotypes observed in many aggressive, poorly-differentiated breast cancers, to which evidence has already linked members of the JAM family. Co-culture models which better recapitulate the complexity of the breast cancer microenvironment than mono-cultures (Holliday et al., 2009) may offer promise in dissecting the relative cellular contributions of JAMs to tumour progression at a reductionist level.

\section{JAMs as novel potential drug targets in breast cancer}

The pleiotrophic roles of JAM family members in regulating both the breast epithelium and cells of the microenvironment may suggest JAMs as novel therapeutic targets for the future management of breast cancer. Whether by aiming to block migratory behaviour, angiogenesis, proliferation or to promote polarisation and differentiation, selective 
pharmacological targeting of JAM molecules could prove particularly useful in cancers that overexpress one or more JAMs. This naturally pre-supposes that JAMs are causally involved in the disease process rather than simply acting as passive biomarkers, a fact that remains to be solidified. However, irrespective of the last caveat, another facet worth exploring is the potential of targeting JAMs to promote drug delivery. Since tight junctions (TJs) as a whole are primary regulators of paracellular transport across epithelial cells (Gonzalez-Mariscal et al., 2005), successful drug delivery may require modulation of TJ proteins to allow drug molecules to pass (Matsuhisa et al., 2009). However disruption of TJ proteins for drug delivery purposes is a double-edged sword, given the risk of disrupting homeostatic mechanisms of polarity, differentiation and migration which are tightly regulated by TJs in normal tissues and whose dysregulation may themselves promote tumourigenesis.

As yet, there are no cancer therapies on the market which specifically target tight junctions. However several tight junction proteins have been described as receptors for specific molecules or organisms, and as such, these might provide valid and novel targets for drug delivery. A particular precedent exists with the claudin family of TJ proteins; Claudins-3 and -4 having been suggested as drug delivery targets since they act as the receptor for Clostridium perfringens enterotoxin (CPE). The ability of CPE to rapidly and specifically lyse cells expressing claudin- 3 or -4 could potentially be exploited in the treatment of breast cancers over-expressing these proteins (Katahira et al., 1997; Morin, 2005; Santin et al., 2007; Santin et al., 2007). Sub-lytic doses of CPE could alternatively be used to compromise TJs thus enhancing the influx of drug molecules across the epithelium. This could be of particular benefit in accessing hypoxic tumour cores, around which the tumour cells may be very tightly packed and thus relatively inaccessible to chemotherapeutic drugs. To date CPE administration has been shown to reduce growth of claudin- 4 overexpressing pancreatic tumour cells (Michl et al., 2001; Michl et al., 2003), but their potential use in other cancer settings remains an open question.

How JAM molecules might be therapeutically targeted also remains an unanswered question, but one could predict value in using monoclonal antibodies or small molecule inhibitors to block the signalling functions which contribute to processes such as migration and angiogenesis. However, to date, the role of JAMs as chemotherapeutic targets (or even prognostic/predictive biomarkers) in the clinical setting of breast cancer has yet to be elucidated and validated. Following the lead of JAM-A as a potential biomarker and therapeutic target for breast cancer (McSherry et al., 2009; Gotte et al., 2010; McSherry et al., 2011; Murakami et al., 2011), we speculate that this will be a lucrative area of research in the future.

\section{Conclusion}

To conclude, breast cancer remains a leading cause of cancer worldwide (Jemal et al., 2008), and the search for new targets of prognostic and therapeutic relevance will continue particularly in this era where semi-personalised medicine is becoming more of a likelihood than an aspiration.

This chapter has attempted to summarize the known roles of the JAM family in controlling cell adhesion, polarity and barrier function, and their emerging roles in controlling functional behaviours within cells of the breast tumour microenvironment which promote cancer progression. Finally, it introduced the topic of JAM as a potential drug target in breast cancer; whether to directly influence JAM-dependent oncogenic signalling or indeed to interfere with cell-cell adhesion for the purposes of enhancing drug delivery. Continued 
expansion in our understanding of the cell and molecular biology of JAMs and their roles in tumour progression may open up new horizons supporting their evaluation as breast cancer biomarkers and drug targets of the future.

\section{References}

Alpaugh, ML, Lee, MC, Nguyen, M, Deato, M, Dishakjian, L et al. (2000). Myoepithelialspecific CD44 shedding contributes to the anti-invasive and antiangiogenic phenotype of myoepithelial cells. Exp Cell Res, Vol. 261, No. 1, (2000), pp 150-8

Arrate, MP, Rodriguez, JM, Tran, TM, Brock, TA \& Cunningham, SA (2001). Cloning of human junctional adhesion molecule 3 (JAM3) and its identification as the JAM2 counter-receptor. J Biol Chem, Vol. 276, No. 49, (2001), pp 45826-32

Asahara, T, Takahashi, T, Masuda, H, Kalka, C, Chen, D et al. (1999). VEGF contributes to postnatal neovascularization by mobilizing bone marrow-derived endothelial progenitor cells. EMBO J, Vol. 18, No. 14, (1999), pp 3964-72

Aurrand-Lions, M, Duncan, L, Ballestrem, C \& Imhof, BA (2001). JAM-2, a novel immunoglobulin superfamily molecule, expressed by endothelial and lymphatic cells. J Biol Chem, Vol. 276, No. 4, (2001), pp 2733-41

Aurrand-Lions, M, Johnson-Leger, C, Wong, C, Du Pasquier, L \& Imhof, BA (2001). Heterogeneity of endothelial junctions is reflected by differential expression and specific subcellular localization of the three JAM family members. Blood, Vol. 98, No. 13, (2001), pp 3699-707

Aurrand-Lions, M, Lamagna, C, Dangerfield, JP, Wang, S, Herrera, P et al. (2005). Junctional adhesion molecule-C regulates the early influx of leukocytes into tissues during inflammation. J Immunol, Vol. 174, No. 10, (2005), pp 6406-15

Awatef, M, Olfa, G, Rim, C, Asma, K, Kacem, M et al. (2011). Physical activity reduces breast cancer risk: A case-control study in Tunisia. Cancer Epidemiol, Vol. No. (2011), 1877$783 x$

Azari, BM, Marmur, JD, Salifu, MO, Cavusoglu, E, Ehrlich, YH et al. (2010). Silencing of the F11R gene reveals a role for F11R/JAM-A in the migration of inflamed vascular smooth muscle cells and in atherosclerosis. Atherosclerosis, Vol. 212, No. 1, (2010), pp 197-205

Babinska, A, Kedees, MH, Athar, H, Ahmed, T, Batuman, $\mathrm{O}$ et al. (2002). F11-receptor (F11R/JAM) mediates platelet adhesion to endothelial cells: role in inflammatory thrombosis. Thromb Haemost, Vol. 88, No. 5, (2002), pp 843-50

Babinska, A, Kedees, MH, Athar, H, Sobocki, T, Sobocka, MB et al. (2002). Two regions of the human platelet F11-receptor (F11R) are critical for platelet aggregation, potentiation and adhesion. Thromb Haemost, Vol. 87, No. 4, (2002), pp 712-21

Barsky, SH (2003). Myoepithelial mRNA expression profiling reveals a common tumorsuppressor phenotype. Exp Mol Pathol, Vol. 74, No. 2, (2003), pp 113-22

Bazzoni, G \& Dejana, E (2004). Endothelial cell-to-cell junctions: molecular organization and role in vascular homeostasis. Physiol Rev, Vol. 84, No. 3, (2004), pp 869-901

Bazzoni, G, Martinez-Estrada, OM, Orsenigo, F, Cordenonsi, M, Citi, S et al. (2000). Interaction of junctional adhesion molecule with the tight junction components ZO1, cingulin, and occludin. J Biol Chem, Vol. 275, No. 27, (2000), pp 20520-6 
Bland, KI \& Copeland, EM. (1998). The Breast: Comprehensive Management of Benign and Malignant Diseases (edition),

Boettner, B, Govek, EE, Cross, J \& Van Aelst, L (2000). The junctional multidomain protein AF-6 is a binding partner of the Rap1A GTPase and associates with the actin cytoskeletal regulator profilin. Proc Natl Acad Sci U S A, Vol. 97, No. 16, (2000), pp 9064-9

Bradfield, PF, Scheiermann, C, Nourshargh, S, Ody, C, Luscinskas, FW et al. (2007). JAM-C regulates unidirectional monocyte transendothelial migration in inflammation. Blood, Vol. 110, No. 7, (2007), pp 2545-55

Brennan, K, Offiah, G, McSherry, EA \& Hopkins, AM (2010). Tight junctions : a barrier to the initiation and progression of breast cancer? J Biomed Biotechnol, 2010; 2010:460607 (2010)

Burger, RA (2011). Overview of anti-angiogenic agents in development for ovarian cancer. Gynecol Oncol, Vol. 121, No. 1, (2011), pp 230-8

Cera, MR, Del Prete, A, Vecchi, A, Corada, M, Martin-Padura, I et al. (2004). Increased DC trafficking to lymph nodes and contact hypersensitivity in junctional adhesion molecule-A-deficient mice. J Clin Invest, Vol. 114, No. 5, (2004), pp 729-38

Cera, MR, Fabbri, M, Molendini, C, Corada, M, Orsenigo, F et al. (2009). JAM-A promotes neutrophil chemotaxis by controlling integrin internalization and recycling. $J$ Cell Sci, Vol. 122, No. Pt 2, (2009), pp 268-77

Clarke, CA, Purdie, DM \& Glaser, SL (2006). Population attributable risk of breast cancer in white women associated with immediately modifiable risk factors. BMC Cancer, Vol. 6, No. (2006), pp 170

Collins, LC, Tamimi, RM, Baer, HJ, Connolly, JL, Colditz, GA et al. (2005). Outcome of patients with ductal carcinoma in situ untreated after diagnostic biopsy: results from the Nurses' Health Study. Cancer, Vol. 103, No. 9, (2005), pp 1778-84

Cooke, VG, Naik, MU \& Naik, UP (2006). Fibroblast growth factor-2 failed to induce angiogenesis in junctional adhesion molecule-A-deficient mice. Arterioscler Thromb Vasc Biol, Vol. 26, No. 9, (2006), pp 2005-11

Corada, M, Chimenti, S, Cera, MR, Vinci, M, Salio, M et al. (2005). Junctional adhesion molecule-A-deficient polymorphonuclear cells show reduced diapedesis in peritonitis and heart ischemia-reperfusion injury. Proc Natl Acad Sci U S A, Vol. 102, No. 30, (2005), pp 10634-9

Cunningham, SA, Arrate, MP, Rodriguez, JM, Bjercke, RJ, Vanderslice, P et al. (2000). A novel protein with homology to the junctional adhesion molecule. Characterization of leukocyte interactions. J Biol Chem, Vol. 275, No. 44, (2000), pp 34750-6

Ebnet, K, Aurrand-Lions, M, Kuhn, A, Kiefer, F, Butz, S et al. (2003). The junctional adhesion molecule (JAM) family members JAM-2 and JAM-3 associate with the cell polarity protein PAR-3: a possible role for JAMs in endothelial cell polarity. J Cell Sci, Vol. 116, No. Pt 19, (2003), pp 3879-91

Ebnet, K, Schulz, CU, Meyer Zu Brickwedde, MK, Pendl, GG \& Vestweber, D (2000). Junctional adhesion molecule interacts with the PDZ domain-containing proteins AF-6 and ZO-1. J Biol Chem, Vol. 275, No. 36, (2000), pp 27979-88 
Ebnet, K, Suzuki, A, Horikoshi, Y, Hirose, T, Meyer Zu Brickwedde, MK et al. (2001). The cell polarity protein ASIP/PAR-3 directly associates with junctional adhesion molecule (JAM). EMBO J, Vol. 20, No. 14, (2001), pp 3738-48

Fanning, AS, Ma, TY \& Anderson, JM (2002). Isolation and functional characterization of the actin binding region in the tight junction protein ZO-1. FASEB J, Vol. 16, No. 13, (2002), pp 1835-7

Farabegoli, F, Champeme, MH, Bieche, I, Santini, D, Ceccarelli, C et al. (2002). Genetic pathways in the evolution of breast ductal carcinoma in situ. J Pathol, Vol. 196, No. 3, (2002), pp 280-6

Fiedler, W, Graeven, U, Ergun, S, Verago, S, Kilic, N et al. (1997). Vascular endothelial growth factor, a possible paracrine growth factor in human acute myeloid leukemia. Blood, Vol. 89, No. 6, (1997), pp 1870-5

Gonzalez-Mariscal, L, Nava, P \& Hernandez, S (2005). Critical role of tight junctions in drug delivery across epithelial and endothelial cell layers. J Membr Biol, Vol. 207, No. 2, (2005), pp 55-68

Goswami, S, Sahai, E, Wyckoff, JB, Cammer, M, Cox, D et al. (2005). Macrophages promote the invasion of breast carcinoma cells via a colony-stimulating factor-1/epidermal growth factor paracrine loop. Cancer Res, Vol. 65, No. 12, (2005), pp 5278-83

Gotte, M, Mohr, C, Koo, CY, Stock, C, Vaske, AK et al. (2010). miR-145-dependent targeting of junctional adhesion molecule $\mathrm{A}$ and modulation of fascin expression are associated with reduced breast cancer cell motility and invasiveness. Oncogene, Vol. 29, No. 50, (2010), pp 6569-80

Gou, HF, Chen, XC, Zhu, J, Jiang, M, Yang, Y et al. (2011). Expressions of COX-2 and VEGF$\mathrm{C}$ in gastric cancer: correlations with lymphangiogenesis and prognostic implications. J Exp Clin Cancer Res, Vol. 30, No. (2011), pp 14

Gudjonsson, T, Ronnov-Jessen, L, Villadsen, R, Rank, F, Bissell, MJ et al. (2002). Normal and tumor-derived myoepithelial cells differ in their ability to interact with luminal breast epithelial cells for polarity and basement membrane deposition. J Cell Sci, Vol. 115, No. Pt 1, (2002), pp 39-50

Gupta, SK, Pillarisetti, K \& Ohlstein, EH (2000). Platelet agonist F11 receptor is a member of the immunoglobulin superfamily and identical with junctional adhesion molecule (JAM): regulation of expression in human endothelial cells and macrophages. IUBMB Life, Vol. 50, No. 1, (2000), pp 51-6

Gutwein, P, Schramme, A, Voss, B, Abdel-Bakky, MS, Doberstein, K et al. (2009). Downregulation of junctional adhesion molecule-A is involved in the progression of clear cell renal cell carcinoma. Biochem Biophys Res Commun, Vol. 380, No. 2, (2009), pp 387-91

Hahn, WC \& Weinberg, RA (2002). Rules for making human tumor cells. N Engl J Med, Vol. 347, No. 20, (2002), pp 1593-603

Hamazaki, Y, Itoh, M, Sasaki, H, Furuse, M \& Tsukita, S (2002). Multi-PDZ domain protein 1 (MUPP1) is concentrated at tight junctions through its possible interaction with claudin-1 and junctional adhesion molecule. J Biol Chem, Vol. 277, No. 1, (2002), pp 455-61 
Hanahan, D \& Folkman, J (1996). Patterns and emerging mechanisms of the angiogenic switch during tumourigenesis. Cell, Vol. 86, No. 3, (1996), pp 353-64

Hanby, AM \& Hughes, TA (2008). In situ and invasive lobular neoplasia of the breast. Histopathology, Vol. 52, No. 1, (2008), pp 58-66

Harrison, SA, Hayes, SC \& Newman, B (2009). Age-related differences in exercise and quality of life among breast cancer survivors. Med Sci Sports Exerc, Vol. 42, No. 1, (2009), pp 67-74

Hirabayashi, S, Tajima, M, Yao, I, Nishimura, W, Mori, H et al. (2003). JAM4, a junctional cell adhesion molecule interacting with a tight junction protein, MAGI-1. Mol Cell Biol, Vol. 23, No. 12, (2003), pp 4267-82

Holliday, DL, Brouilette, KT, Markert, A, Gordon, LA \& Jones, JL (2009). Novel multicellular organotypic models of normal and malignant breast: tools for dissecting the role of the microenvironment in breast cancer progression. Breast Cancer Res, Vol. 11, No. 1, (2009), pp R3, 1465-542X

Hou, Y, Rabquer, BJ, Gerber, ML, Del Galdo, F, Jimenez, SA et al. (2009). Junctional adhesion molecule-A is abnormally expressed in diffuse cutaneous systemic sclerosis skin and mediates myeloid cell adhesion. Ann Rheum Dis, Vol. No. (2009), 1468-2060

Howell, A \& Evans, GD (2011). Hormone replacement therapy and breast cancer. Recent Results Cancer Res, Vol. 188, No. (2011), pp 115-24

$\mathrm{Hu}, \mathrm{M}, \mathrm{Yao}, \mathrm{J}$, Cai, L, Bachman, KE, van den Brule, F et al. (2005). Distinct epigenetic changes in the stromal cells of breast cancers. Nat Genet, Vol. 37, No. 8, (2005), pp 899-905

$\mathrm{Hu}, \mathrm{M}$, Yao, J, Carroll, DK, Weremowicz, S, Chen, H et al. (2008). Regulation of in situ to invasive breast carcinoma transition. Cancer Cell, Vol. 13, No. 5, (2008), pp 394-406

Hwang, ES, DeVries, S, Chew, KL, Moore, DH, 2nd, Kerlikowske, K et al. (2004). Patterns of chromosomal alterations in breast ductal carcinoma in situ. Clin Cancer Res, Vol. 10, No. 15, (2004), pp 5160-7

Itoh, M, Nelson, CM, Myers, CA \& Bissell, MJ (2007). Rap1 integrates tissue polarity, lumen formation, and tumorigenic potential in human breast epithelial cells. Cancer Res, Vol. 67, No. 10, (2007), pp 4759-66

Itoh, M, Sasaki, H, Furuse, M, Ozaki, H, Kita, T et al. (2001). Junctional adhesion molecule (JAM) binds to PAR-3: a possible mechanism for the recruitment of PAR-3 to tight junctions. J Cell Biol, Vol. 154, No. 3, (2001), pp 491-7

Jemal, A, Siegel, R, Ward, E, Hao, Y, Xu, J et al. (2008). Cancer statistics, 2008. CA Cancer J Clin, Vol. 58, No. 2, (2008), pp 71-96

Johnson-Leger, CA, Aurrand-Lions, M, Beltraminelli, N, Fasel, N \& Imhof, BA (2002). Junctional adhesion molecule-2 (JAM-2) promotes lymphocyte transendothelial migration. Blood, Vol. 100, No. 7, (2002), pp 2479-86

Kasler, M, Polgar, C \& Fodor, J (2009). [Current status of treatment for early-stage invasive breast cancer.]. Oro Hetil, Vol. 150, No. 22, (2009), pp 1013-21, 0030-6002 (Print)

Katahira, J, Sugiyama, H, Inoue, N, Horiguchi, Y, Matsuda, M et al. (1997). Clostridium perfringens enterotoxin utilizes two structurally related membrane proteins as functional receptors in vivo. J Biol Chem, Vol. 272, No. 42, (1997), pp 26652-8

Key, T, Verkasalo, P \& Banks, E (2001). Epidemiology of breast cancer. Lancet Oncol, Vol. 2, No. (2001), pp 133-40, 
Kleinman, HK, Koblinski, J, Lee, S \& Engbring, J (2001). Role of basement membrane in tumor growth and metastasis. Surg Oncol Clin N Am, Vol. 10, No. 2, (2001), pp 32938

Koenen, RR, Pruessmeyer, J, Soehnlein, O, Fraemohs, L, Zernecke, A et al. (2009). Regulated release and functional modulation of junctional adhesion molecule $\mathrm{A}$ by disintegrin metalloproteinases. Blood, Vol. 113, No. 19, (2009), pp 4799-809

Kornecki, E, Walkowiak, B, Naik, UP \& Ehrlich, YH (1990). Activation of human platelets by a stimulatory monoclonal antibody. J Biol Chem, Vol. 265, No. 17, (1990), pp 10042-8

Lamagna, C, Hodivala-Dilke, KM, Imhof, BA \& Aurrand-Lions, M (2005). Antibody against junctional adhesion molecule-C inhibits angiogenesis and tumor growth. Cancer Res, Vol. 65, No. 13, (2005), pp 5703-10

Lewis, CE \& Hughes, R (2007). Inflammation and breast cancer. Microenvironmental factors regulating macrophage function in breast tumours: hypoxia and angiopoietin-2. Breast Cancer Res, Vol. 9, No. 3, (2007), pp 209

Li, X, Stankovic, M, Lee, BP, Aurrand-Lions, M, Hahn, CN et al. (2009). JAM-C induces endothelial cell permeability through its association and regulation of \{beta\} 3 integrins. Arterioscler Thromb Vasc Biol, Vol. 29, No. 8, (2009), pp 1200-6

Liang, TW, DeMarco, RA, Mrsny, RJ, Gurney, A, Gray, A et al. (2000). Characterization of huJAM: evidence for involvement in cell-cell contact and tight junction regulation. Am J Physiol Cell Physiol, Vol. 279, No. 6, (2000), pp C1733-43

Liu, Y, Nusrat, A, Schnell, FJ, Reaves, TA, Walsh, S et al. (2000). Human junction adhesion molecule regulates tight junction resealing in epithelia. J Cell Sci, Vol. 113 ( Pt 13), No. (2000), pp 2363-74

Luissint, AC, Lutz, PG, Calderwood, DA, Couraud, PO \& Bourdoulous, S (2008). JAM-Lmediated leukocyte adhesion to endothelial cells is regulated in cis by alpha4beta1 integrin activation. J Cell Biol, Vol. 183, No. 6, (2008), pp 1159-73

Ma, XJ, Dahiya, S, Richardson, E, Erlander, M \& Sgroi, DC (2009). Gene expression profiling of the tumor microenvironment during breast cancer progression. Breast Cancer Res, Vol. 11, No. 1, (2009), pp R7

Malergue, F, Galland, F, Martin, F, Mansuelle, P, Aurrand-Lions, M et al. (1998). A novel immunoglobulin superfamily junctional molecule expressed by antigen presenting cells, endothelial cells and platelets. Mol Immunol, Vol. 35, No. 17, (1998), pp 1111-9

Mandell, KJ, McCall, IC \& Parkos, CA (2004). Involvement of the junctional adhesion molecule-1 (JAM1) homodimer interface in regulation of epithelial barrier function. J Biol Chem, Vol. 279, No. 16, (2004), pp 16254-62

Mandell, KJ \& Parkos, CA (2005). The JAM family of proteins. Adv Drug Deliv Rev, Vol. 57, No. 6, (2005), pp 857-67

Martin-Padura, I, Lostaglio, S, Schneemann, M, Williams, L, Romano, M et al. (1998). Junctional adhesion molecule, a novel member of the immunoglobulin superfamily that distributes at intercellular junctions and modulates monocyte transmigration. J Cell Biol, Vol. 142, No. 1, (1998), pp 117-27

Martinez-Estrada, OM, Villa, A, Breviario, F, Orsenigo, F, Dejana, E et al. (2001). Association of junctional adhesion molecule with calcium/calmodulin-dependent serine 
protein kinase (CASK/LIN-2) in human epithelial caco-2 cells. J Biol Chem, Vol. 276, No. 12, (2001), pp 9291-6

Matsuhisa, K, Kondoh, M, Takahashi, A \& Yagi, K (2009). Tight junction modulator and drug delivery. Expert Opin Drug Deliv, Vol. 6, No. 5, (2009), pp 509-15

McCave, EJ, Cass, CA, Burg, KJ \& Booth, BW (2010). The normal microenvironment directs mammary gland development. J Mammary Gland Biol Neoplasia, Vol. 15, No. 3, pp 291-9

McSherry, EA, Brennan, K, Hudson, L, Hill, AD \& Hopkins, AM (2011). Breast cancer cell migration is regulated through junctional adhesion molecule-A-mediated activation of Rap1 GTPase. Breast Cancer Res, Vol. 13, No. 2, (2011), pp R31

McSherry, EA, McGee, SF, Jirstrom, K, Doyle, EM, Brennan, DJ et al. (2009). JAM-A expression positively correlates with poor prognosis in breast cancer patients. Int J Cancer, Vol. 125, No. 6, (2009), pp 1343-51

Michl, P, Barth, C, Buchholz, M, Lerch, MM, Rolke, M et al. (2003). Claudin-4 expression decreases invasiveness and metastatic potential of pancreatic cancer. Cancer Res, Vol. 63, No. 19, (2003), pp 6265-71

Michl, P, Buchholz, M, Rolke, M, Kunsch, S, Lohr, M et al. (2001). Claudin-4: a new target for pancreatic cancer treatment using Clostridium perfringens enterotoxin. Gastroenterology, Vol. 121, No. 3, (2001), pp 678-84

Mishima, A, Suzuki, A, Enaka, M, Hirose, T, Mizuno, K et al. (2002). Over-expression of PAR-3 suppresses contact-mediated inhibition of cell migration in MDCK cells. Genes Cells, Vol. 7, No. 6, (2002), pp 581-96

Molica, S, Vitelli, G, Levato, D, Gandolfo, GM \& Liso, V (1999). Increased serum levels of vascular endothelial growth factor predict risk of progression in early B-cell chronic lymphocytic leukaemia. Br J Haematol, Vol. 107, No. 3, (1999), pp 605-10

Monkhouse, S. (2007). Clinical Anatomy (edition), Churchill Livingstone Elsevier,

Moog-Lutz, C, Cave-Riant, F, Guibal, FC, Breau, MA, Di Gioia, Y et al. (2003). JAML, a novel protein with characteristics of a junctional adhesion molecule, is induced during differentiation of myeloid leukemia cells. Blood, Vol. 102, No. 9, (2003), pp 3371-8

Mori, H, Hirabayashi, S, Shirasawa, M, Sugimura, H \& Hata, Y (2004). JAM4 enhances hepatocyte growth factor-mediated branching and scattering of Madin-Darby canine kidney cells. Genes Cells, Vol. 9, No. 9, (2004), pp 811-9

Morin, PJ (2005). Claudin proteins in human cancer: promising new targets for diagnosis and therapy. Cancer Res, Vol. 65, No. 21, (2005), pp 9603-6

Morris, AP, Tawil, A, Berkova, Z, Wible, L, Smith, CW et al. (2006). Junctional Adhesion Molecules (JAMs) are differentially expressed in fibroblasts and co-localize with ZO-1 to adherens-like junctions. Cell Commun Adhes, Vol. 13, No. 4, (2006), pp 23347

Murakami, M, Francavilla, C, Torselli, I, Corada, M, Maddaluno, L et al. (2010). Inactivation of junctional adhesion molecule-A enhances antitumoral immune response by promoting dendritic cell and T lymphocyte infiltration. Cancer Res, Vol. 70, No. 5, (2010), pp 1759-65

Murakami, M, Giampietro, C, Giannotta, M, Corada, M, Torselli, I, Orsenigo, F, Cocito, A, d'Ario, G, Mazzarol, G, Confalonieri, S, Di Fiore, PP \& Dejana, E (2011). Abrogation 
of junctional adhesion molecule-a expression induces cell apoptosis and reduces breast cancer progression. PLoS One. Vol. 6, No. 6, (2011), e21242. Epub 2011 Jun 17

Murdoch, C, Giannoudis, A \& Lewis, CE (2004). Mechanisms regulating the recruitment of macrophages into hypoxic areas of tumors and other ischemic tissues. Blood, Vol. 104, No. 8, (2004), pp 2224-34

Nagamatsu, G, Ohmura, M, Mizukami, T, Hamaguchi, I, Hirabayashi, S et al. (2006). A CTX family cell adhesion molecule, JAM4, is expressed in stem cell and progenitor cell populations of both male germ cell and hematopoietic cell lineages. Mol Cell Biol, Vol. 26, No. 22, (2006), pp 8498-506

Naik, MU, Mousa, SA, Parkos, CA \& Naik, UP (2003). Signaling through JAM-1 and alphavbeta3 is required for the angiogenic action of bFGF: dissociation of the JAM1 and alphavbeta3 complex. Blood, Vol. 102, No. 6, (2003), pp 2108-14

Naik, MU, Naik, TU, Suckow, AT, Duncan, MK \& Naik, UP (2008). Attenuation of junctional adhesion molecule-A is a contributing factor for breast cancer cell invasion. Cancer Res, Vol. 68, No. 7, (2008), pp 2194-203

Naik, MU \& Naik, UP (2006). Junctional adhesion molecule-A-induced endothelial cell migration on vitronectin is integrin alpha v beta 3 specific. J Cell Sci, Vol. 119, No. Pt 3, (2006), pp 490-9

Naik, MU, Vuppalanchi, D \& Naik, UP (2003). Essential role of junctional adhesion molecule-1 in basic fibroblast growth factor-induced endothelial cell migration. Arterioscler Thromb Vasc Biol, Vol. 23, No. 12, (2003), pp 2165-71

Naik, UP, Ehrlich, YH \& Kornecki, E (1995). Mechanisms of platelet activation by a stimulatory antibody: cross-linking of a novel platelet receptor for monoclonal antibody F11 with the Fc gamma RII receptor. Biochem J, Vol. 310 ( Pt 1), No. (1995), pp 155-62

Naik, UP, Naik, MU, Eckfeld, K, Martin-DeLeon, P \& Spychala, J (2001). Characterization and chromosomal localization of JAM-1, a platelet receptor for a stimulatory monoclonal antibody. J Cell Sci, Vol. 114, No. Pt 3, (2001), pp 539-47

Nathanson, SD, Wachna, DL, Gilman, D, Karvelis, K, Havstad, S et al. (2001). Pathways of lymphatic drainage from the breast. Ann Surg Oncol, Vol. 8, No. 10, (2001), pp 83743

Nava, P, Capaldo, CT, Koch, S, Kolegraff, K, Rankin, CR et al. JAM-A regulates epithelial proliferation through Akt/beta-catenin signalling. EMBO Rep, Vol. 12, No. 4, pp 314-20

Nava, P, Capaldo, CT, Koch, S, Kolegraff, K, Rankin, CR et al. (2011). JAM-A regulates epithelial proliferation through Akt/beta-catenin signalling. EMBO Rep, Vol. 12, No. 4, (2011), pp 314-20

Ogasawara, N, Kojima, T, Go, M, Fuchimoto, J, Kamekura, R et al. (2009). Induction of JAMA during differentiation of human THP-1 dendritic cells. Biochem Biophys Res Commun, Vol. 389, No. 3, (2009), pp 543-9

Orimo, A, Gupta, PB, Sgroi, DC, Arenzana-Seisdedos, F, Delaunay, T et al. (2005). Stromal fibroblasts present in invasive human breast carcinomas promote tumor growth and angiogenesis through elevated SDF-1/CXCL12 secretion. Cell, Vol. 121, No. 3, (2005), pp 335-48 
Orlova, VV, Economopoulou, M, Lupu, F, Santoso, S \& Chavakis, T (2006). Junctional adhesion molecule-C regulates vascular endothelial permeability by modulating VE-cadherin-mediated cell-cell contacts. J Exp Med, Vol. 203, No. 12, (2006), pp 2703-14

Ostermann, G, Weber, KS, Zernecke, A, Schroder, A \& Weber, C (2002). JAM-1 is a ligand of the beta(2) integrin LFA-1 involved in transendothelial migration of leukocytes. Nat Immunol, Vol. 3, No. 2, (2002), pp 151-8

Ozaki, H, Ishii, K, Arai, H, Horiuchi, H, Kawamoto, T et al. (2000). Junctional adhesion molecule (JAM) is phosphorylated by protein kinase $\mathrm{C}$ upon platelet activation. Biochem Biophys Res Commun, Vol. 276, No. 3, (2000), pp 873-8

Page, DL, Dupont, WD, Rogers, LW, Jensen, RA \& Schuyler, PA (1995). Continued local recurrence of carcinoma 15-25 years after a diagnosis of low grade ductal carcinoma in situ of the breast treated only by biopsy. Cancer, Vol. 76, No. 7, (1995), pp 1197-200

Palmer, G, Busso, N, Aurrand-Lions, M, Talabot-Ayer, D, Chobaz-Peclat, V et al. (2007). Expression and function of junctional adhesion molecule- $C$ in human and experimental arthritis. Arthritis Res Ther, Vol. 9, No. 4, (2007), pp R65

Palmeri, D, van Zante, A, Huang, CC, Hemmerich, S \& Rosen, SD (2000). Vascular endothelial junction-associated molecule, a novel member of the immunoglobulin superfamily, is localized to intercellular boundaries of endothelial cells. J Biol Chem, Vol. 275, No. 25, (2000), pp 19139-45

Parris, JJ, Cooke, VG, Skarnes, WC, Duncan, MK \& Naik, UP (2005). JAM-A expression during embryonic development. Dev Dyn, Vol. 233, No. 4, (2005), pp 1517-24

Patel, NS, Muneer, A, Blick, C, Arya, M \& Harris, AL (2009). Targeting vascular endothelial growth factor in renal cell carcinoma. Tumour Biol, Vol. 30, No. 5-6, (2009), pp 292-9

Perotti, C, Wiedl, T, Florin, L, Reuter, H, Moffat, S et al. (2009). Characterization of mammary epithelial cell line HC11 using the NIA 15k gene array reveals potential regulators of the undifferentiated and differentiated phenotypes. Differentiation, Vol. 78, No. 5, (2009), pp 269-82

Polyak, K \& Hu, M (2005). Do myoepithelial cells hold the key for breast tumor progression? J Mammary Gland Biol Neoplasia, Vol. 10, No. 3, (2005), pp 231-47

Praetor, A, McBride, JM, Chiu, H, Rangell, L, Cabote, L et al. (2009). Genetic deletion of JAM$\mathrm{C}$ reveals a role in myeloid progenitor generation. Blood, Vol. 113, No. 9, (2009), pp 1919-28

Rabquer, BJ, Amin, MA, Teegala, N, Shaheen, MK, Tsou, PS et al. (2010). Junctional adhesion molecule-C is a soluble mediator of angiogenesis. J Immunol, Vol. 185, No. 3, (2010), pp 1777-85

Rabquer, BJ, Pakozdi, A, Michel, JE, Gujar, BS, Haines, GK, 3rd et al. (2008). Junctional adhesion molecule $\mathrm{C}$ mediates leukocyte adhesion to rheumatoid arthritis synovium. Arthritis Rheum, Vol. 58, No. 10, (2008), pp 3020-9

Reeves, GK, Patterson, J, Vessey, MP, Yeates, D \& Jones, L (2000). Hormonal and other factors in relation to survival among breast cancer patients. Int J Cancer, Vol. 89, No. 3, (2000), pp 293-9 
Reynolds, LE, Watson, AR, Baker, M, Jones, TA, D'Amico, G et al. (2010). Tumour angiogenesis is reduced in the Tc1 mouse model of Down's syndrome. Nature, Vol. 465, No. 7299, pp 813-7

Riss, J, Khanna, C, Koo, S, Chandramouli, GV, Yang, HH et al. (2006). Cancers as wounds that do not heal: differences and similarities between renal regeneration/repair and renal cell carcinoma. Cancer Res, Vol. 66, No. 14, (2006), pp 7216-24

Robinson, BD, Sica, GL, Liu, YF, Rohan, TE, Gertler, FB et al. (2009). Tumor microenvironment of metastasis in human breast carcinoma: a potential prognostic marker linked to hematogenous dissemination. Clin Cancer Res, Vol. 15, No. 7, (2009), pp 2433-41

Rod, NH, Hansen, AM, Nielsen, J, Schnohr, P \& Gronbaek, M (2009). Low-risk factor profile, estrogen levels, and breast cancer risk among postmenopausal women. Int J Cancer, Vol. 124, No. 8, (2009), pp 1935-40

Sadlonova, A, Novak, Z, Johnson, MR, Bowe, DB, Gault, SR et al. (2005). Breast fibroblasts modulate epithelial cell proliferation in three-dimensional in vitro co-culture. Breast Cancer Res, Vol. 7, No. 1, (2005), pp R46-59

Sainsbury, JR, Anderson, TJ \& Morgan, DA (2000). ABC of breast diseases: breast cancer. BMJ, Vol. 321, No. 7263, (2000), pp 745-50

Sakaguchi, T, Nishimoto, M, Miyagi, S, Iwama, A, Morita, Y et al. (2006). Putative "stemness" gene jam-B is not required for maintenance of stem cell state in embryonic, neural, or hematopoietic stem cells. Mol Cell Biol, Vol. 26, No. 17, (2006), pp 6557-70

Sanders, ME, Schuyler, PA, Dupont, WD \& Page, DL (2005). The natural history of lowgrade ductal carcinoma in situ of the breast in women treated by biopsy only revealed over 30 years of long-term follow-up. Cancer, Vol. 103, No. 12, (2005), pp 2481-4

Santin, AD, Bellone, S, Marizzoni, M, Palmieri, M, Siegel, ER et al. (2007). Overexpression of claudin-3 and claudin- 4 receptors in uterine serous papillary carcinoma: novel targets for a type-specific therapy using Clostridium perfringens enterotoxin (CPE). Cancer, Vol. 109, No. 7, (2007), pp 1312-22

Santin, AD, Bellone, S, Siegel, ER, McKenney, JK, Thomas, M et al. (2007). Overexpression of Clostridium perfringens enterotoxin receptors claudin-3 and claudin-4 in uterine carcinosarcomas. Clin Cancer Res, Vol. 13, No. 11, (2007), pp 3339-46

Santoso, S, Orlova, VV, Song, K, Sachs, UJ, Andrei-Selmer, CL et al. (2005). The homophilic binding of junctional adhesion molecule-C mediates tumor cell-endothelial cell interactions. J Biol Chem, Vol. 280, No. 43, (2005), pp 36326-33

Santoso, S, Sachs, UJ, Kroll, H, Linder, M, Ruf, A et al. (2002). The junctional adhesion molecule 3 (JAM-3) on human platelets is a counterreceptor for the leukocyte integrin Mac-1. J Exp Med, Vol. 196, No. 5, (2002), pp 679-91

Scheiermann, C, Colom, B, Meda, P, Patel, NS, Voisin, MB et al. (2009). Junctional adhesion molecule-C mediates leukocyte infiltration in response to ischemia reperfusion injury. Arterioscler Thromb Vasc Biol, Vol. 29, No. 10, (2009), pp 1509-15

Sebzda, E, Bracke, M, Tugal, T, Hogg, N \& Cantrell, DA (2002). Rap1A positively regulates T cells via integrin activation rather than inhibiting lymphocyte signaling. Nat Immunol, Vol. 3, No. 3, (2002), pp 251-8 
Shackney, SE \& Silverman, JF (2003). Molecular evolutionary patterns in breast cancer. Adv Anat Pathol, Vol. 10, No. 5, (2003), pp 278-90

Sharma, PS, Sharma, R \& Tyagi, T (2011). VEGF/VEGFR Pathway Inhibitors as AntiAngiogenic Agents: Present and Future. Curr Cancer Drug Targets, Vol. No. (2011), 1873-5576

Sircar, M, Bradfield, PF, Aurrand-Lions, M, Fish, RJ, Alcaide, P et al. (2007). Neutrophil transmigration under shear flow conditions in vitro is junctional adhesion molecule-C independent. J Immunol, Vol. 178, No. 9, (2007), pp 5879-87

Sobocka, MB, Sobocki, T, Banerjee, P, Weiss, C, Rushbrook, JI et al. (2000). Cloning of the human platelet F11 receptor: a cell adhesion molecule member of the immunoglobulin superfamily involved in platelet aggregation. Blood, Vol. 95, No. 8, (2000), pp 2600-9

Sorlie, T, Perou, CM, Tibshirani, R, Aas, T, Geisler, S et al. (2001). Gene expression patterns of breast carcinomas distinguish tumor subclasses with clinical implications. Proc Natl Acad Sci U S A, Vol. 98, No. 19, (2001), pp 10869-74

Stellos, K, Langer, H, Gnerlich, S, Panagiota, V, Paul, A et al. (2010). Junctional adhesion molecule A expressed on human CD34+ cells promotes adhesion on vascular wall and differentiation into endothelial progenitor cells. Arterioscler Thromb Vasc Biol, Vol. 30, No. 6, pp 1127-36

Sugano, Y, Takeuchi, M, Hirata, A, Matsushita, H, Kitamura, T et al. (2008). Junctional adhesion molecule-A, JAM-A, is a novel cell-surface marker for long-term repopulating hematopoietic stem cells. Blood, Vol. 111, No. 3, (2008), pp 1167-72

Tajima, M, Hirabayashi, S, Yao, I, Shirasawa, M, Osuga, J et al. (2003). Roles of immunoglobulin-like loops of junctional cell adhesion molecule 4; involvement in the subcellular localization and the cell adhesion. Genes Cells, Vol. 8, No. 9, (2003), pp 759-68

Tirona, MT, Sehgal, R \& Ballester, O (2010). Prevention of breast cancer (part I): epidemiology, risk factors, and risk assessment tools. Cancer Invest, Vol. 28, No. 7, (2010), pp 743-50

van 't Veer, LJ, Dai, H, van de Vijver, MJ, He, YD, Hart, AA et al. (2002). Gene expression profiling predicts clinical outcome of breast cancer. Nature, Vol. 415, No. 6871, (2002), pp 530-6

van de Vijver, MJ, He, YD, van't Veer, LJ, Dai, H, Hart, AA et al. (2002). A gene-expression signature as a predictor of survival in breast cancer. N Engl J Med, Vol. 347, No. 25, (2002), pp 1999-2009

Van Meter, ME \& Kim, ES (2010). Bevacizumab: current updates in treatment. Curr Opin Oncol, Vol. 22, No. 6, pp 586-91

Walker, RA \& Martin, CV (2007). The aged breast. J Pathol, Vol. 211, No. 2, (2007), pp 232-40

Weaver, VM, Fischer, AH, Peterson, OW \& Bissell, MJ (1996). The importance of the microenvironment in breast cancer progression: recapitulation of mammary tumourigenesis using a unique human mammary epithelial cell model and a threedimensional culture assay. Biochem Cell Biol, Vol. 74, No. 6, (1996), pp 833-51 
Williams, C, Ponten, F, Moberg, C, Soderkvist, P, Uhlen, M et al. (1999). A high frequency of sequence alterations is due to formalin fixation of archival specimens. Am J Pathol, Vol. 155, No. 5, (1999), pp 1467-71

Woodfin, A, Reichel, CA, Khandoga, A, Corada, M, Voisin, MB et al. (2007). JAM-A mediates neutrophil transmigration in a stimulus-specific manner in vivo: evidence for sequential roles for JAM-A and PECAM-1 in neutrophil transmigration. Blood, Vol. 110, No. 6, (2007), pp 1848-56

Wyckoff, J, Wang, W, Lin, EY, Wang, Y, Pixley, F et al. (2004). A paracrine loop between tumor cells and macrophages is required for tumor cell migration in mammary tumors. Cancer Res, Vol. 64, No. 19, (2004), pp 7022-9

Yoshikumi, Y, Ohno, H, Suzuki, J, Isshiki, M, Morishita, Y et al. (2008). Up-regulation of JAM-1 in AR42J cells treated with activin A and betacellulin and the diabetic regenerating islets. Endocr J, Vol. 55, No. 4, (2008), pp 757-65

Zen, K, Babbin, BA, Liu, Y, Whelan, JB, Nusrat, A et al. (2004). JAM-C is a component of desmosomes and a ligand for CD11b/CD18-mediated neutrophil transepithelial migration. Mol Biol Cell, Vol. 15, No. 8, (2004), pp 3926-37

Zen, K, Liu, Y, McCall, IC, Wu, T, Lee, W et al. (2005). Neutrophil migration across tight junctions is mediated by adhesive interactions between epithelial coxsackie and adenovirus receptor and a junctional adhesion molecule-like protein on neutrophils. Mol Biol Cell, Vol. 16, No. 6, (2005), pp 2694-703 


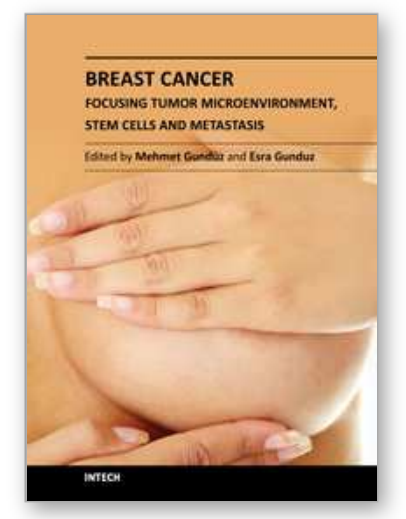

\author{
Breast Cancer - Focusing Tumor Microenvironment, Stem cells and \\ Metastasis \\ Edited by Prof. Mehmet Gunduz
}

ISBN 978-953-307-766-6

Hard cover, 584 pages

Publisher InTech

Published online 14, December, 2011

Published in print edition December, 2011

Cancer is the leading cause of death in most countries and its consequences result in huge economic, social and psychological burden. Breast cancer is the most frequently diagnosed cancer type and the leading cause of cancer death among females. In this book, we discussed characteristics of breast cancer cell, role of microenvironment, stem cells and metastasis for this deadly cancer. We hope that this book will contribute to the development of novel diagnostic as well as therapeutic approaches.

\title{
How to reference
}

In order to correctly reference this scholarly work, feel free to copy and paste the following:

Gozie Offiah, Kieran Brennan and Ann M. Hopkins (2011). Junctional Adhesion Molecules (JAMs) - New Players in Breast Cancer?, Breast Cancer - Focusing Tumor Microenvironment, Stem cells and Metastasis, Prof. Mehmet Gunduz (Ed.), ISBN: 978-953-307-766-6, InTech, Available from:

http://www.intechopen.com/books/breast-cancer-focusing-tumor-microenvironment-stem-cells-andmetastasis/junctional-adhesion-molecules-jams-new-players-in-breast-cancer-

\section{INTECH}

open science | open minds

\section{InTech Europe}

University Campus STeP Ri

Slavka Krautzeka 83/A

51000 Rijeka, Croatia

Phone: +385 (51) 770447

Fax: +385 (51) 686166

www.intechopen.com

\section{InTech China}

Unit 405, Office Block, Hotel Equatorial Shanghai

No.65, Yan An Road (West), Shanghai, 200040, China

中国上海市延安西路65号上海国际贵都大饭店办公楼 405 单元

Phone: +86-21-62489820

Fax: +86-21-62489821 
(C) 2011 The Author(s). Licensee IntechOpen. This is an open access article distributed under the terms of the Creative Commons Attribution 3.0 License, which permits unrestricted use, distribution, and reproduction in any medium, provided the original work is properly cited. 